\title{
Challenges of Parenthood after Divorce in Albania
}

\author{
PhD Jeta Shkurti (Toçila) \\ Department of Pedagogy-Psychology, Faculty of Social Sciences, University of Tirana \\ Email: jetashkurti@yahoo.com
}

\section{Doi:10.5901/mjss.2016.v7n3s1p129}

\begin{abstract}
After the divorce, in addition of changing the marital status, changes arise also in parenthood. Suddenly there are two houses with an adult responsible for the children. What are the challenges facing parents already divorced? Do the Albanian parents support each other during this process? Does the parenthood exist or society is not yet ready for this form of care? This research established on the basis of these questions is qualitative, where the data were collected through semi-structured interviews. They were transcribed and analyzed by thematic content. Interviewees were mothers and fathers of the Albanian capital, who had at least one child. They were interviewed a year after the announcement of the decision by the Court of Tirana for the dissolution of marriage. The data represent the experiences and opinions of interviewees who had similar but also different custody regime. From the search results that the main challenges faced by parents concerned with the lack of cooperation with the other parent, parental alienation, difficulty of maintaining the close relationship with the children, adapting to a new way of living, and hope of resident parent for a greater support in parenting by the non-resident parent. The study helps the divorced parents or those in the process of divorce, as well as professionals in the field.
\end{abstract}

Keywords: parenthood, divorce, parenting together, custody, parental alienation

\section{Introduction}

\subsection{The challenges of parenthood after divorce}

Recently in our country the phenomenon of divorce has become more vulnerable than before. There is no wonder that in a palace or class is at least one child of divorced parents. Working with divorced parents in order to reduce the effects of divorce on children, is one of the important aspects of the phenomenon. Still there is no awareness that psychological counseling during and after a divorce is necessary, however, some promising steps are made in this direction. Since 2004 with the adoption of amendments to the Family Code of the Republic of Albania, during the trial of the marriage dissolutions, takes a special role the psychologist or social worker. From this period, my interest was shown for the phenomenon of divorce in Albania. As an expert recognized by the Court of Tirana in matters of custody of children in cases of the marriage dissolutions, I had the opportunity to contact more than 300 couples during the phase before, during and after divorce. I had the opportunity to observe each year causes, motives of divorces, behaviors and attitudes of partners to each other, the children's reactions. But what made me more curious and more demanding to research further was the situation after the divorce. This is the stage of challenges for parents, as well as for children. It is not yet easy to accept the fact that after divorce, the former partners must meet and talk to each other again for the child's problems. The typical Albanian divorce has been not only the separation of the couple, but also of the tribes. Meetings of children with the non-resident parent have been rare. But Albanian society expressed in most cases the wish to be Europe. In this context, the issues of divorce must be treated and considered similar to those of European countries. Consequently, at this stage they need more support. The beginning of supporting parenthood after divorce is the awareness of parents that a child needs both parents. This is emphasized in the Convention on the Rights of the Child. The purpose of the study is to understand what are the changes and challenges of parenting after divorce. The search is focused on parents, their experiences and opinions on the situation after the divorce.

\subsection{Divorce}

In the past, before the 90's in Albania, few cases of divorce were present. The socialist state and society did not accept "simple" reasons to divorce. There had to be a major and proven cause for the court to give the divorce. When women came out as brides from the father's house, they were ordered to behave well and to be devoted since there was no 
turning back. For most couples, though they were not married in church, marriage was accompanied by the phrase "for better and for worse till death do us part". Divorce was not easy. While in other countries it was about gender division of roles as the man to ensure their livelihoods and the woman who cared for the children, and then began the movement for gender equality, in our country before the 90 s both men and women worked and educated, but their independence was not at the same levels. In fact, the dictatorial regime limited both sexes in terms of independence, even within the walls of the house. In other countries, when women began to work and to be educated, they provided a good income. Gender balance changed. To us, the situation remained constant. It was the state regulator of all, despite the desires and potentials. In Albania before the enactment of the Family Code in 2003, there were recognized as grounds for divorcing violation of infidelity, incurable mental illness, and criminal conviction of one of the spouses. Today, under Article 132 of the Family Code, the dissolution of marriage at the request of one of the spouses is due to continuous quarrels, maltreatment, severe insults, adultery, incurable mental illness, criminal conviction of one of spouses or for any other reason that makes repeated violations of obligations arising from the marriage, joint life becomes impossible and the marriage has lost its purpose for the plaintiff spouse or both spouses. Also under Article 129 of the Family Code, the divorce can happen today due to the interruption of life together when the spouses live separately in fact since 3 years.

The process of dissolution of marriage in our country is realized soon but the delay can occur also. Usually procedures are simple and in a normal flow the divorce is carried out within 2 months, but if the court does not create confidence that all possibilities of reconciliation of spouses are excluded, it may postpone the announcement of the decision to 1 year, based on Article 136 of the Family Code. Divorce brings big changes in life. According to TolkkiNikkonen (1985) divorce can be regarded as a crisis situation that can change lives for the better. Pohjola (1999) states that divorce has become an option for many people to change their lives. Families should be supported during the marriage in parenting and relationship issues. It is natural for a family to have problems, but in order to reduce the number of divorces it is necessary the support. If parents can afford divorce and parenting after it constructively, it can have a positive effect on children. Galambos and Ehrenberg (1997) stated that divorced parents who are able to maintain good relations with each other and have cooperative parenthood, not only protect the children from the potential negative effects, but also they can provide models for children how to resolve the conflicts and how to negotiate relationships.

\subsection{Parenthood}

Parenthood is a lifelong role and dedication. Parents, children and the environment form the role of parenthood. Parenting is developed by parent-child interaction. Being a parent can be a rewarding and enjoyable thing, but also it has many challenges. In modern societies, parenting is a choice. Furthermore, having children can be seen as a project (Hokkanen 2005). To become parent in Albania, in most cases is a defined task since when wearing the crown. It is expected immediately the birth of a child from a married couple. Even the most common wishes in a marriage ceremony are "Wish for you to have successors", "Wish for the couple to be inherited with a son", which means that the Albanians celebrate and wish the heritage, and not the couple coexistence itself. Pressure to be inherited is made to couple from families, relatives, neighbors and even by just acquaintances. A childless couple who has more than two years of marriage, is viewed with compassion by others with the idea "as sin, they can't have children", excluding the fact that the couple may have chosen not to become a parent for a period of time. Especially for couples living in the capital is an increase of childless years after marriage. For young couples in our country now as in other countries it is believed that the transition to parenthood is an event that brings changes. The couple's life is not the same after birth of a child. Becoming a parent for the first time includes the reorganization of perceived roles and relations for the mother, father and the couple as a whole (Brooks - Gunn \& Sidl Fuligni 2002, 83). Transition contains not only positive changes. Parents should keep in mind that negative changes are also included as positive ones. Parenthood is not a feature or role, and not a set of tasks that an adult takes as responsibility just becoming a parent. Recently parenthood is not an obligation or right. Parenthood is a relationship between parent and child. (Tamminen, 2004, 67.) According to Emery (1994) an essential part of parenthood is the relationship between parents. If the relationship between the couple, parents goes to divorce, it is important to understand that parents get not divorced also with children. Therefore, the relationship between the parents should remain. Children are connection bridges of their parents. Under the International Convention on the Rights of the Child, Article 18, both parents have equal responsibilities for children's development. After the divorce, changes the nature of parenthood. Children spend some time with their mother and the rest of time with their father. Parents face new situations that have not experienced before. They have to adapt to new forms of parenting. 


\subsection{Support for Family and Parenting in Albania}

In our country, unlike other countries has not statutory institution or organization caring for family and parenting before, during and after divorce. There are several non-profit organizations such as TLAS, which provide legal assistance to women during divorce, which can not afford financially the court costs. Centre of services and legal integrated practices QSHPLI offers also legal assistance. These organizations offer their support as the only legal representative of the parties in need and do not provide psycho-social or economic assistance for the just divorced couple or their psychological counseling in terms of parenting after divorce. Community centers of mental health provide advice to general focus and not specifically to the problems of divorce. Psychologists and psychiatrists working there are not recognized by the public regarding the help they may provide. None from the parents interviewed by me, has not ever had contact with a psychologist to these centers. To my knowledge there is an association of parenting, but their activities depend on the acquired projects and may be limited in duration. State institutions may have on their staff, directorates with many beautiful names, but their efficiency and visibility for the concerned public is zero.

\subsection{Custody of Children}

Mason (1994) states that the division of child's care after the divorce, is a new idea and today custody is based on the principle "best interest of the child". Before, the Albanian customary law has considered children as the property of the father. XX century took into account the role of the mother as the primary caregiver of the child and then the best interests of the child would determine the mother as the main caregiver. Maccoby, Depner and Mnookin (1990) stipulate that it is beneficial for the child to interact with both parents constantly. In different countries there are different types of custody. In our country are used some samples and are not taken into consideration the specifics of the case. There are many reasons why the court does so. One of them is that that are followed judicial practices and some inexperienced judges in the field of children do not tend to bring innovation in their decisions. Also the role of the judicial psychologist is still seen as a piece that forces law and not as a necessity and importance in a dispute with the object of dissolution of marriage. It would be a revolution if it would define a day of common parenting or parenting together. In all cases it is determined the formula: "Entrusting for growing up and education of the children to $X$ parent and the right of meeting and alimony to $Y$ parent". Usually to a non-resident parent, a term used regularly in the estimates for the court, is fixed the right of meeting once every two weeks or once a month. With great strain are determined the rights of meeting every week or even more.

\section{Literature Review}

I am referring to, because of the ease of access, two similar studies in Finland by Kääriäinen (2008) and Hokkanen (2005). Kääriäinen (2008) in a paper entitled "Divorce presents a challenge for parents" interviewed divorced parents. The paper was conducted within the project for the welfare of children who deals with parenting after divorce. The aim of the project was awareness of the situation of children and the reduction of the bitter experiences of children by the divorcing of parents. Research led by Kääriäinen (2008) was based on the experiences of parents and aimed to find out how parenting was during and after divorce or what changes occur during a divorce. Mykkänen-Hänninen and Paajanen (2007) ranked the co-parenting characteristics:

- Mutually cooperative relationship on children's issues

- Holding and maintaining a positive image of the other parent

- Taking into account the views of the child

- The ability to protect children from conflict between parents

- Flexibility in the conflict situation

Findings of Hokkanen (2005) showed that the time and place influenced the experience of parent-child relationship. He also indicated that the mother's relationship with the father is mediated by the child and the relationship of the father with the mother is mediated also by money, economic result of divorce or payment of alimony.

\section{Research}

The purpose of this paper is to study the experiences and opinions of divorced parents in Albania. The aim was to find out what changes on parenting after divorce and what challenges brings the divorce. It will also show how parenting works towards cooperation between former partners and how this relationship affects the parenting of interviewees. 
Further it tries to convey how parents coped with divorce and whether they were in need of support at this stage.

The questions raised are:

- How changes parenting after divorce?

- What kinds of challenges have emerged on parenting after divorce?

- How was the cooperation between parents after divorce?

- Do they have the need for support on parenting after divorce?

\section{Research Methods}

Qualitative methods are the ones that come to help us in this paper, since we are dealing with experiences and opinions. There are prepared semi-structured interviews with defined topics. Interviewees have completed previously general data in a form, and then through direct interview we had the opportunity to examine them more broadly.

\section{Data Collection}

Data were collected during the period 2009-2011. There were in total 8 divorced women and 8 divorced men. All together had 21 children from 1 to 2 children each. They have been married for 3 to 15 years. The plan of "de facto" visits of children was different, though "de jure" in judicial decisions had similarities. The frequency of meetings of non-resident parent was from every day of the week to once a year. Criteria for the selection of the interviewees were to have been married for more than 1 year and have had minor children. They were not known to each other and none of them was the former partner of anyone by interviewees. Interviews were conducted in complete privacy conditions. They had 3 main topics: Parenting together, change in parenting after divorce and the welfare and coping after divorce. The interviews were recorded and literally transcribed. Then they were organized and analyzed by topic.

\section{Changes and Challenges}

Let's see in row three main topics where are focused the interviews.

- The cooperation and decision making

Cooperation with former partner is one of the most important aspects of post-divorce relationship. It must be said that it is not easy to start co-parenting after a divorce. New rules should be established to parenting after divorce in order to have a functional relationship. This will have a positive impact on parenting. The nature of cooperation affects to some degree in parenting. If the relationship would work, former partners could have a good relationship and would be able to cooperate. This would support and facilitate parenting after divorce. According to someone, which had smoothly coparenting after divorce, the reason was that they have previously agreed regarding visits and alimony. The dissolution of marriage with agreement has been positive for the parties, because they have put everything on a document. In this case, the beneficiaries have been both parents and children.

\subsection{Changes}

According to interviewees parenting changes after divorce. The main change is described in terms of the relationship with the former partner, relationships with children and dealing with responsibilities.

\section{Relations with children}

They are described as changed after the divorce. Both sides react immediately to changes in the family. Now they have to adapt to this new environment and the new form of relations, for which they were not prepared. Children are found between two houses that are not asked by them, but they need to get used to. As parents and children, do not feel comfortable with each other. The child blames the parent when not blaming itself for the changed situation. The parent feels bad and feels like separating also from the child, except than separating from the partner. Also it feels the weight of responsibility already doubled, once shared with the partner. To improve the relationship with the child, the parent dedicates the maximum hours to the child and even meets every requirement, once called whim. This is the typical relationship between parent and child after a divorce.

Relations with the former partner

Because of the mentality and social pressure, the relationships with former partner tend to be conflicting or with significant lack of communication. Usually Albanian parents use their children as a messenger for the other parent. Even 
if they may wish for the continuation of the relationship, the public opinion is the one that prevents them to a significant extent. After divorce, parental alienation syndrome appears to both parents. There is no alienating or alienated division, as both parents do not escape both roles appearing simultaneously.

\subsection{Responsibilities}

Some of the interviewees mention the many responsibilities that come after the divorce, taking playing two roles, as the non-resident parent most of the time does not respond to certain obligations. Others mention that after the divorce the non-resident parent finally remembers that it has children and finally acknowledges the parental responsibility. There are others who feel just the same even after divorce, because also during marriage they exercised the same responsibilities, reason for which the divorce occurred.

\subsection{Welfare and Coping}

Difficulty to manage alone with children after divorce is the main concern. But in our country, the ties with the family of origin are still strong. Therefore, the support from family of origin after the divorce is still seen as a protective factor in terms of facing difficulties. Grandparents remain heroes, saviors, even in situations of divorce. But economic difficulties pose the biggest problem of parents after divorce. Living in rented houses, job instability, low wages and high prices, make the children's lives after divorce of parents undergo changes and to give effect to many aspects of welfare. Resident parents are forced to perform more than one job to succeed, but it will affect the relationship with the child in the period when he/she most needed to.

\section{Discussions and Conclusions}

Most parents gave the same answer to the question what makes positive parenting after divorce, compared with the model provided by Kääriäinen (2008). The study shows that if the four aspects of the model are taken into account, they would help parents after the divorce process, causing less damage to them and the children. In the pattern of challenges of parenthood after divorce, parenthood is in the middle and surrounded by 4 aspects: planning divorce together, sharing responsibilities, support each other and interaction obligation. From my interviewees none of them had been part of the first aspect of planning along the divorce. Depending on the motive of separation, one or the other did not agree initially for the divorce and after some time it agreed with reality. Consequently, given that one of the partners has had opposition to divorce, even the aspect of supporting each other was not implemented from the beginning. After a while, after the decision became final, the parents have not followed the obligation for interaction for the sake of the highest interest of the child by not leaving aside the anger and disagreements. Over time, parents have realized that their welfare influenced the child's welfare. As a result they have returned again to four aspects of parenting replacing from the beginning the right relations with ex-partner. It should be noted that not all interviewees have achieved this. As stated in the introduction of the paper, the Albanian mentality and traditions still influence the behaviors and attitudes toward divorce. Although it is desired by parents sharing responsibilities, in our country full responsibility is still exercised by the resident parent and non-resident parent in most cases only enjoys de facto the right of visit and alimony. Everything else is realized by resident parent. One of the model challenges was the interaction of the parents. Depending on the cases, it was the interaction. There were parents that for the child's sake, accepted to enter into negotiations with the other parent, but there were others that for the sake of pride and anger, refused to interact, especially when one of the parents was remarried. To minimize conflict between them, the parents need to support each other. According to interviewees, the parenting facilitated when they enjoyed the support of the other parent. But in most cases, the support was received from family members, friends and second partner. They wanted to have support and assistance also from professionals, but they could not find someone. Parenting faces many challenges during and after divorce. It has to do with the relationship with the child and it is a lifelong relationship. While love ends between the couple, co-parenting should continue. Parents implemented various plans of visits, particularly different to those of the court decision. Parent-child relationship had changed inevitably. They were made distant. In summary, the main changes to parenting after divorce were: parenting happened in a way where each used to parent separately, relationships with children changed because they were not daily relationships, parents had a greater responsibility since they were only one parent at home. Cooperation with the other parent to the children's interests, maintaining a close relationship with the child, coping with the increased responsibilities and new ways to manage and care for all, by finding the support from outside. I hope this paper can help the divorced parents, or those who are under process of divorce, as well as professionals of the field who may encounter problems of parenthood and divorce. 


\section{References}

Amato, P.R. "The Consequences of Divorce for Adults and Children". Journal of Marriage and the Family 62: 1269 - 1287. (2000).

Bernardes, Jon, Family Studies, an Introduction. London: Routledge 1997.

Brooks-Gunn, Jeanne \& Sidle Fuligni, Allison, Meeting the Challenges of New Parenthood - Responsibilities, Advice, and Perceptions. 2002

Clarke-Stewart, Alison \& Brentano, Cornelia, Divorce - Causes and Consequences. New Haven and London: Yale University Press. 2006

Emery, R.E., and Dillon, P. "Conceptualizing the Divorce Process: Renegotiating Boundaries of Intimacy and Power in the Divorced Family System". Family Relations 43: 374-379. (1994).

Freitas, Maria José, Friesenhahn, Günter, Frost, Elizabeth \& Michailidis, Maria, Children, Young People and Families - Examining social work practice in Europe. Children, Young People and Families in a European Context. Rome: Carocci editore 2005

Hogan, Margaret Monahan, Finality \& Marriage. Milwaukee: Marquette University Press.1993

Karvinen-Niinikoski, S. Tapola-Haapala, M., \& Kääriäinen, A. 21 Nov 2012 Challenges of divorce, Interventions and children [Eron haasteet, väliintulot ja lapset]. Kääriäinen, A., Hämäläinen, J. \& Pölkki, P. (eds.). Helsinki: Ensi- ja turvakotien liitto, p. $99-12324$ p

Kautto Mikko, Changes in Age Structure, Family Stability and Dependency. 2002.

O'Loughlin, Steve, Values and Ethics in Social Work with Children and Families. 2008.

In O'Loughlin, Maureen \& O'Loughlin, Steve Social Work with Children \& Families. Second edition. Exeter: Learning Matters Ltd.

Rubin, Herbert \& Rubin, Irene, Qualitative interviewing - The Art of Hearing Data. London: Sage Publications. 1995

Smyth, Bruce \& Weston, Ruth, The Attitudes of Separated Mothers and Fathers to 50/50 Shared Care. Family Matters No. 67 Autumn 2004. 